Nova Southeastern University

Florida

NOVA SOUTHEASTERN

UNIVERSTYY

NSUWorks

Marine \& Environmental Sciences Faculty Articles Department of Marine and Environmental Sciences

$1-1-2013$

\title{
Habitat Characterization, Distribution, and Areal Extent of Deep-sea Coral Ecosystems off Florida, Southeastern U.S.A.
}

John K. Reed

Harbor Branch Oceanographic Institution

Charles G. Messing

Nova Southeastern University, $<<$ span class="elink">messingc@nova.edu

Brian K. Walker

Nova Southeastern University, $<<$ span class="elink">walkerb@nova.edu

Sandra Brooke

Oregon Institute of Marine Biology

Thiago B.S. Correa

University of Miami

See next page for additional authors

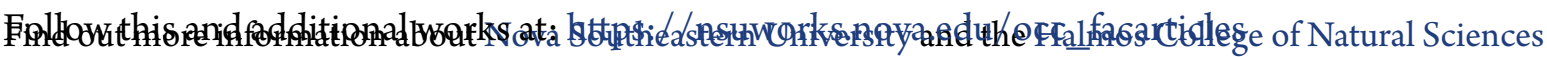

Partaplographarine Biology Commons, and the Oceanography and Atmospheric Sciences and Meteorology Commons

\section{Recommended Citation}

Reed, JK, C Messing, B Walker, S Brooke, T Correa, M Brouwer, and T Udouj (2013) "Habitat characterization, distribution, and areal extent of deep-sea coral ecosystem habitat off Florida, southeastern United States." Caribbean Journal of Science 47(1): 13-30.

This Article is brought to you for free and open access by the Department of Marine and Environmental Sciences at NSUWorks. It has been accepted for inclusion in Marine \& Environmental Sciences Faculty Articles by an authorized administrator of NSUWorks. For more information, please contact nsuworks@nova.edu. 
Authors

Myra Brouwer

South Atlantic Fishery Management Council

Tina Udouj

Florida Fish and Wildlife Commission

\section{Stephanie Farrington}

Harbor Branch Oceanographic Institution 


\title{
Habitat Characterization, Distribution, and Areal Extent of Deep-sea Coral Ecosystems off Florida, Southeastern U.S.A.
}

\author{
John K. Reed ${ }^{1, *}$, Charles Messing ${ }^{2}$, Brian K. WALKer ${ }^{2}$, SANdra Brooke ${ }^{3}$, \\ Thiago B.S. Correa ${ }^{4}$, Myra Brouwer ${ }^{5}$, Tina Udouj ${ }^{6}$, and Stephanie Farrington ${ }^{1}$ \\ ${ }^{1}$ Harbor Branch Oceanographic Institute, Florida Atlantic University, 5600 U.S. 1 North, Fort Pierce, Florida 34946 USA \\ ${ }^{2}$ Nova Southeastern University, 8000 N. Ocean Drive, Dania Beach, Florida 33004 USA \\ ${ }^{3}$ Oregon Institute of Marine Biology, 63466 Boat Basin Road, Charleston, Oregon 97420 USA \\ ${ }^{4}$ University of Miami, Rosenstiel School of Marine and Atmospheric Science, 4600 Rickenbacker Causeway, Miami, \\ Florida 33149 USA \\ ${ }^{5}$ Myra Brouwer, South Atlantic Fishery Management Council, 4055 Faber Place Drive, Suite 201, North Charleston, \\ South Carolina 29405 USA \\ ${ }^{6}$ Tina Udouj, FWC Fish and Wildlife Research Institute, 100 Eighth Ave SE, St. Petersburg, Florida 33701 USA \\ *Corresponding Author email: jreed12@hboi.fau.edu
}

\begin{abstract}
Aвstract.-The deep-sea $(200-1000 \mathrm{~m})$ seafloor off the southeastern U.S. has a variety of extensive deep-sea coral ecosystem (DSCE) habitats including: deep-water coral mounds; various hard-bottom habitats off Florida including the Miami Terrace, Pourtalès Terrace, and deep-water canyons (Agassiz and Tortugas Valleys); and deep island slopes off western Bahamas and northern Cuba. The dominant structure-forming scleractinian corals are Lophelia pertusa and Enallopsammia profunda; other structure-forming taxa include stylasterid corals, gorgonians, black corals, and sponges. This biota is associated with hard-bottom seafloor of variable high-relief topography which can be remotely identified from bathymetric data. NOAA bathymetric contour maps and digital elevation models were used to identify and delineate the areal extent of potential DSCE habitat in the region from northeastern Florida through the Straits of Florida. These were ground-truthed with 241 dives with submersibles and remotely operated vehicles which confirmed deep-sea coral habitat. We estimate a total of $39,910 \mathrm{~km}^{2}$ of DSCE habitat in this region. By comparison, the estimated areal extent of shallow-water coral habitat for all U.S. waters is $36,813 \mathrm{~km}^{2}$. Bottom trawling remains the greatest threat to DSCEs worldwide, and as a result NOAA has established five deep-water Coral Habitat Areas of Particular Concern (CHAPCs), encompassing $62,714 \mathrm{~km}^{2}$ from North Carolina to south Florida, which will protect much of the known deep-sea coral habitat in this region. High-resolution surveys are not only critical to define DSCE habitats but also to define areas devoid of coral and sponge habitats that may allow for potential bottom fisheries and energy development.
\end{abstract}

KEYwORDS.-conservation, deep-sea coral ecosystem, habitat mapping, Lophelia

\section{INTRODUCTION}

Deep-sea coral ecosystems (DSCEs) occur extensively off the southeastern United States from North Carolina to Florida, and within the Straits of Florida between Florida, the Bahamas and Cuba. The southeastern U.S. may have the most extensive areas of deep-sea coral in U.S. waters (Hain and Corcoran 2004); however, this large region is poorly explored and their extent is unknown. Only a few, limited areas of deep-sea habitat has been remotely mapped off Florida (Reed et al.
2005 b, Grasmueck et al. 2006, 2007, Reed 2008), and the percentage of seafloor explored visually with human occupied submersibles and remotely operated vehicles (ROVs) remains small. In the broad sense, DSCEs in this region occur at depths of $50 \mathrm{~m}$ to $>1000 \mathrm{~m}$ and consist of structureforming, deep-water corals (including scleractinian corals, gorgonian octocorals, black corals, and stylasterid hydrozoan corals) and other associated structureforming species such as sponges, bryozoans, and hydroids, all of which may provide habitat to hundreds of species of invertebrates 
and demersal fishes (Lumsden et al. 2007, Partyka et al. 2007, Messing et al. 2008). We refer to deep-sea corals as a loosely defined polyphyletic assemblage of scleractinian corals, zoanthids, black corals, octocorals, and hydrocorals belonging to the phylum Cnidaria (Etnoyer et al. 2006, Lumsden et al. 2007).

Deep-sea coral ecosystems may consist of a variety habitat types including coral banks, bioherms, lithoherms, and hard bottom, and are broadly defined as deepwater coral reefs based on their physical and biological characteristics (Rogers 1999, Roberts et al. 2009). Deep-sea bioherms are mounds of unconsolidated mud and coral debris which may be capped with thickets of live coral. Deep-sea lithoherms, however, are defined as limestone mounds of lithified carbonate rather than unconsolidated mud mounds but are also capped with coral habitat (Neumann et al. 1977). The DSCEs in this region also include other hard-bottom habitats such as exposed rock substrate. These rocky hard-bottom habitats include rock escarpments, rock boulders, pavement, deep island slopes, and karstic topographic features such as deepwater sinkholes, all of which provide substrate for a variety of deep-sea corals and sponges.

High-relief coral mounds (including both bioherms and lithoherms) are common in this region on the Blake Plateau from North Carolina to south Florida and the Bahamas at depths of 400 to $>900 \mathrm{~m}$ and are typically capped with Lophelia pertusa and/or Enallopsammia profunda corals (Stetson et al. 1962, Neumann \& Ball 1970, Neumann et al. 1977, Messing et al. 1990, Paull et al. 2000, Reed et al. 2005 a, 2006, Grasmueck et al. 2007, Ross and Quattrini 2007, Messing et al. 2008). In the Straits of Florida, off southeastern Florida, the continental slope is interrupted by two intermediatedepth terraces (200-600 m): the Miami and Pourtalès Terraces which also provide DSCE hard-bottom habitat. Their surfaces are composed of limestone outcrops and each exhibits high-relief rock ridges, escarpments, and karst-like deep-water sinkholes that provide hard-bottom habitat for corals and sponges (Jordan et al. 1964, Ballard \& Uchupi 1971, Land \& Paull 2000, Reed et al. 2005 a, 2006). A large portion of this region from North Carolina to southern Florida is now protected within the deep-water Coral Habitat Areas of Particular Concern (CHAPCs, Fig. 1) which were established by NOAA (2010), encompassing $62,714 \mathrm{~km}^{2}$. These sites were originally proposed by the South Atlantic Fishery Management Council (SAFMC 2009) which manages commercial fisheries in this region.

The dominant corals forming deep-sea coral habitat deeper than $200 \mathrm{~m}$ in the Straits of Florida are the azooxanthellate, colonial scleractinians L. pertusa and E. profunda with lesser contributions by Madrepora oculata and Solenosmilia variabilis; various species of hydrocorals of the family Stylasteridae; numerous octocorals primarily of the families Paramuriceidae, Isididae, Primnoidae, and Chrysogorgiidae; and several black coral species (Reed et al. 2005 a, 2006, Ross and Nizinski 2007, Messing et al. 2008). In addition, the scleractinian Oculina varicosa forms azooxanthellate coral bioherms off eastern Florida at depths of 70-100 m (Reed 1980, Reed 2002 a,b, Reed et al. 2005 b).

We hypothesize that the deep-water $(>200 \mathrm{~m}$ depth), high-relief (>15 m) topographic features in this region are, in fact, deep-sea coral ecosystem habitats. Our research expeditions using submersibles, ROVs, and Autonomous Underwater Vehicles (AUVs) have documented the distribution, habitat, and biodiversity of these poorly known deep-water habitats. In this paper, we have compiled the distribution of over 400 sites, from northeastern Florida $\left(31^{\circ} \mathrm{N}\right)$ through the Straits of Florida between Florida, Bahamas and Cuba that show high-relief bathymetry, and we predict, probable deepsea coral habitat. Of these, we have groundtruthed 147 sites with 241 submersible and ROV dives. In addition, we have included museum records of deep-water scleractinian corals in this region from historical dredge and trawl samples. By plotting these data onto NOAA digital elevation models and scanned electronic bathymetric contour maps, we map and calculate the areal extent of high-relief topography that we predict 


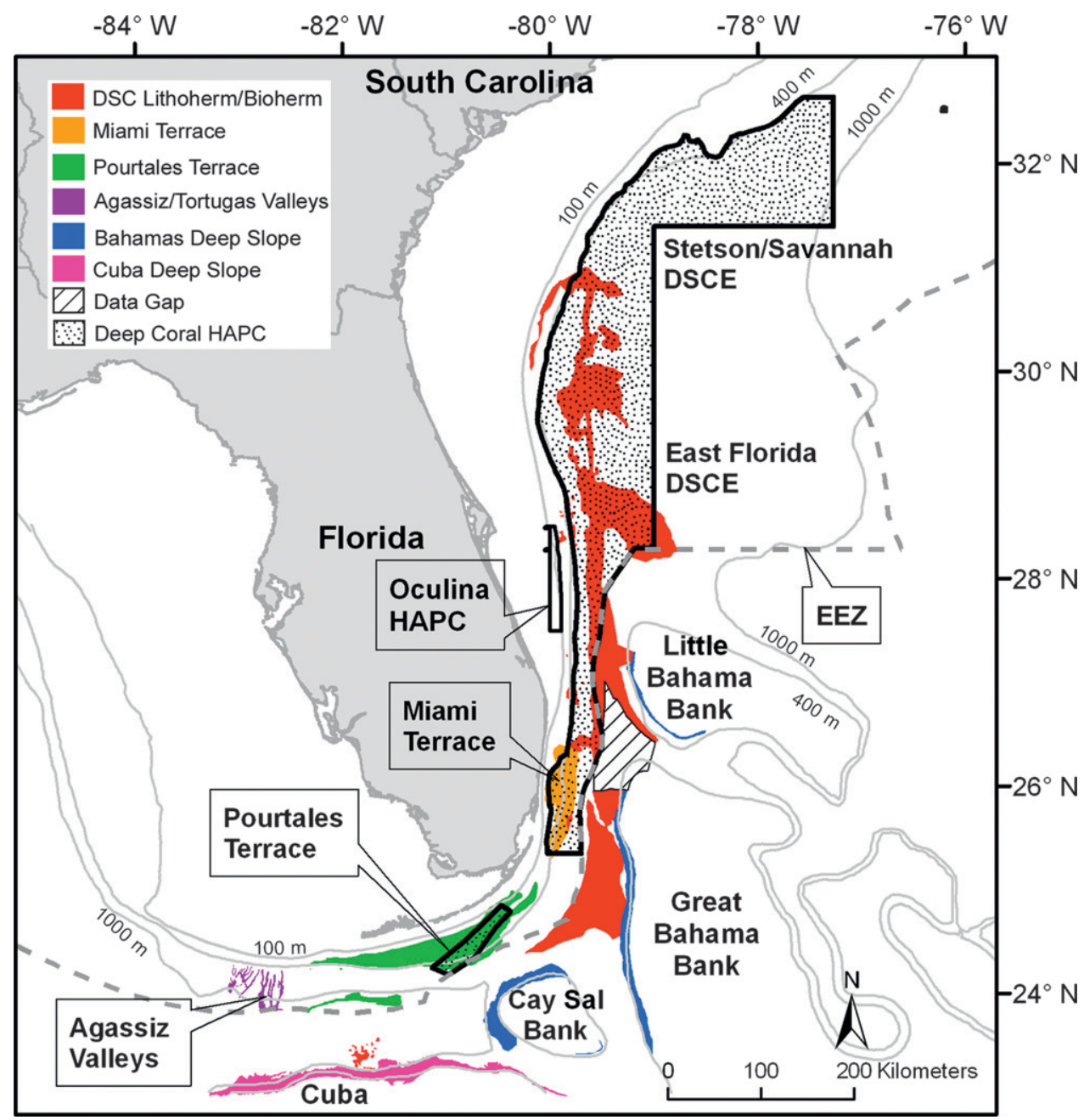

FIG. 1. Regions of deep-sea coral ecosystem (DSCE) habitats mapped from northeastern Florida $\left(31^{\circ} \mathrm{N}\right)$ through the Straits of Florida between Florida, western Bahamas, and northern Cuba. Dashed line= U.S. EEZ; polygons (heavy bold line)= boundaries of deep-water Coral Habitat Areas of Particular Concern (CHAPC) and deep-water Oculina coral HAPC; colored polygons= DSCE habitats (see legend); striped polygon= area of data gap in coastal relief digital elevation model (DEM).

is deep-sea coral ecosystem habitat and classify the various habitat types.

\section{Methods}

The region of study extends from northeastern Florida $\left(31^{\circ} \mathrm{N}\right)$ through the Straits of Florida between Florida, Bahamas and Cuba. Data on the distribution, areal extent, and habitat types of deep-sea coral ecosystems were collected in this region and were compiled in ArcGIS (ArcView ${ }^{\circledR}$, ArcMap $^{\circledR}$ version 9.3). The primary dataset consisted of data collected between 1999 and 2009 from submersible and ROV research dives, side-scan and multibeam sonar mapping with AUVs and shipboard surveys, and benthic video surveys for proposed commercial deep-water liquid natural gas pipelines and ports, and deep-water cables. These data provide precise information on the occurrence and distribution of deepwater coral ecosystem habitats. Submersible and ROV dive tracks, written logs, 
video annotations, collections, in situ photographs and videotapes were recorded and archived at the Harbor Branch Oceanographic Institute (HBOI), Florida Atlantic University. Some data were also compiled by the lead author (J.Reed) for the Southeast Area Monitoring and Assessment Program (SEAMAP, Arendt et al. 2003, Udouj 2007) and for the Southeastern United States Deep-Sea Corals Initiative (SEADESC, Partyka et al. 2007).

In order to define the areal extent of high-relief topography in this region, we scanned and digitized several bathymetric contour maps off eastern Florida and the
Straits of Florida and imported them into ArcGIS. Ideally, multibeam and side-scan sonar maps provide the best resolution for delineating the extent of deep-sea floor features and calculating their dimensions (Roberts et al. 2009). However, in this region these high resolution data are presently limited to a few areas (Grasmueck et al. 2006, 2007, Reed 2008). The best available regional bathymetry was obtained from NOAA's National Geophysical Data Center (NGDC) as coastal relief digital elevation models (DEM) and as scanned regional bathymetric contour maps. Both datasets were necessary because the regional

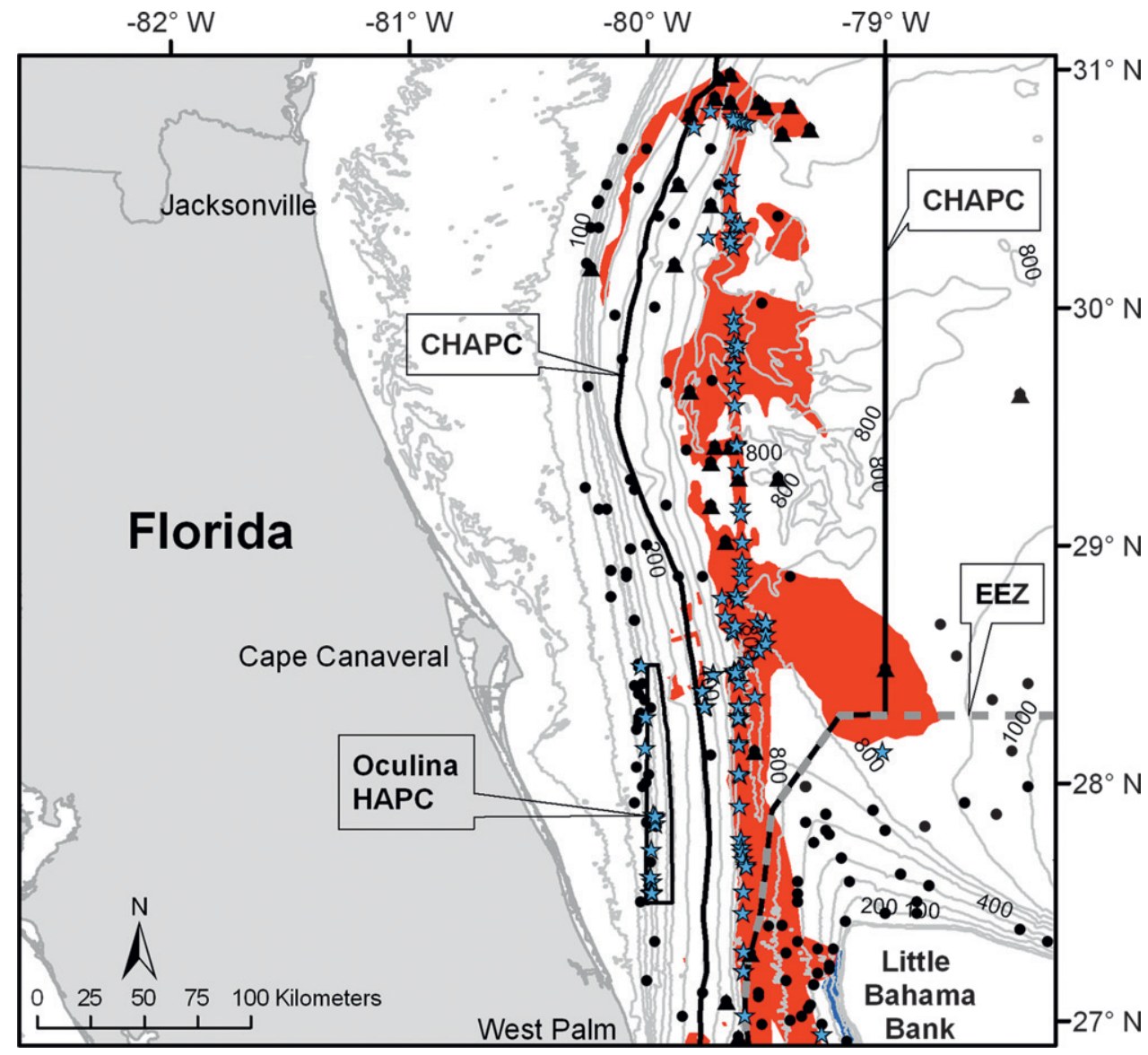

FIG. 2. Regions of deep-sea coral ecosystem (DSCE) habitats mapped off northeastern Florida $\left(31^{\circ} \mathrm{N}\right)$ and northern Straits of Florida. Dashed line= U.S. EEZ; polygons (heavy bold line)= boundaries of deep-water Coral Habitat Areas of Particular Concern (CHAPC) and deep-water Oculina coral HAPC; colored polygons (see Fig. 1 caption for legend)= DSCE habitats; stars= DSCE habitat mapped with ROV, submersible or sonar; triangles= museum records of Lophelia pertusa, Enallopsammia profunda, or Madrepora oculata corals; dots= museum records of other deep-water (>50 m depth) coral species (Cairns 1979, 2000); depth contours in meters. 
contour maps had greater detail that the DEM map lacked, and also contained detailed contours in some data gap areas of the DEM. However, the contour maps were limited because they were only available as TIFF images, not as digitized depth contours.

The NGDC's U.S. Coastal Relief Model Volume 3 provided a comprehensive view of the region, integrating various offshore bathymetry datasets into one seamless representation of the seafloor. Bathymetric data sources included the U.S. National Ocean Service Hydrographic Database, the U.S. Geological Survey, the Monterey Bay Aquarium Research Institute, the U.S.
Army Corps of Engineers, the International Bathymetric Chart of the Caribbean Sea and the Gulf of Mexico project, and various other academic institutions. A custom-sized DEM was downloaded from the NGDC DEM portal, imported into ArcGIS, and hillshaded to provide a 3-D modeled surface illuminated at $45^{\circ}$ sun angle and azimuth.

Scanned regional bathymetric maps were also downloaded from the NGDC website as high resolution images and georeferenced in ArcGIS. These topographic maps of the sea floor provided detailed depth contours illustrating the size, shape and distribution of underwater features.

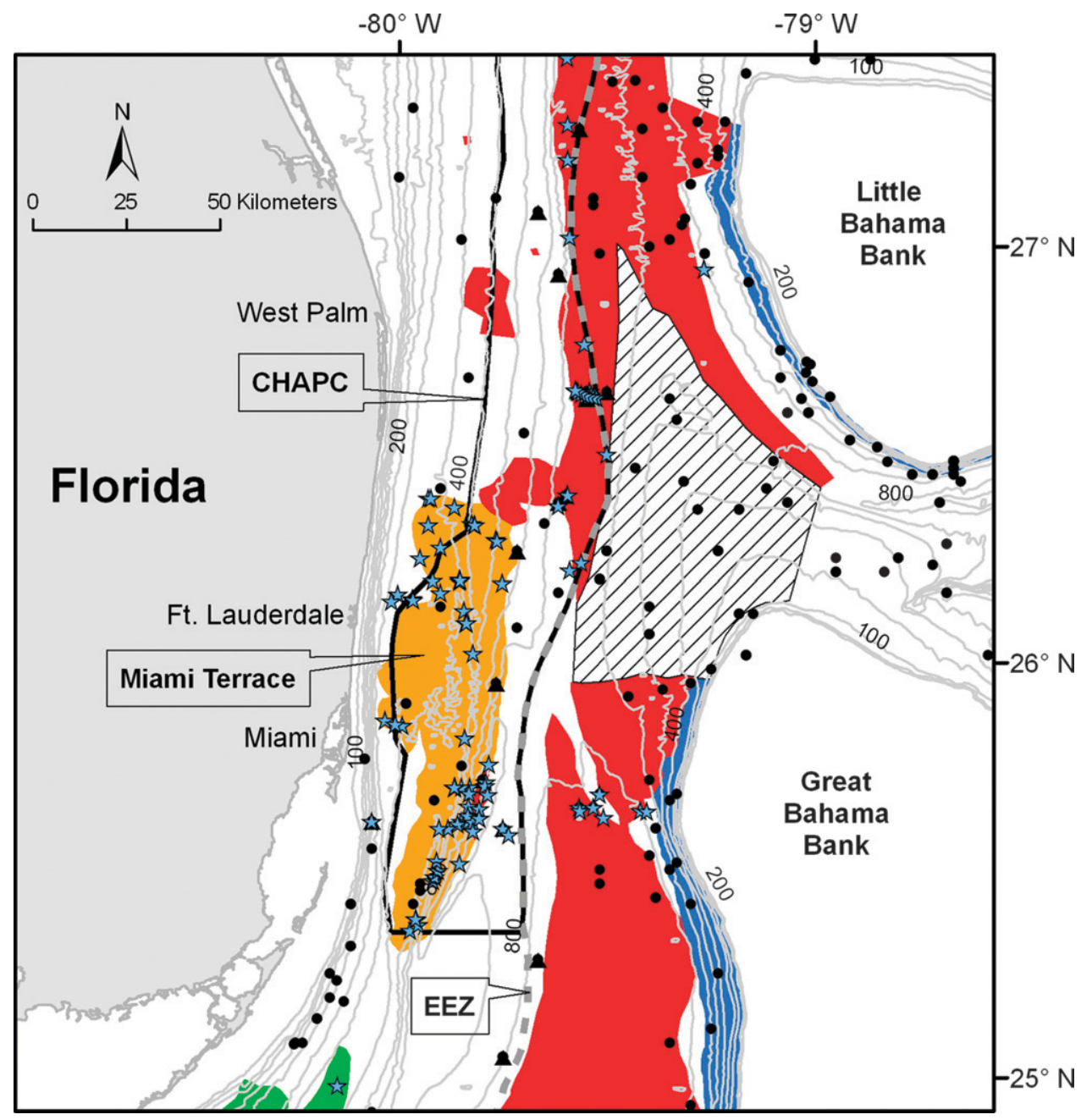

FIG. 3. Regions of deep-sea coral ecosystem (DSCE) habitats mapped off southeast Florida, including Straits of Florida. (Same legend as Fig. 2) 


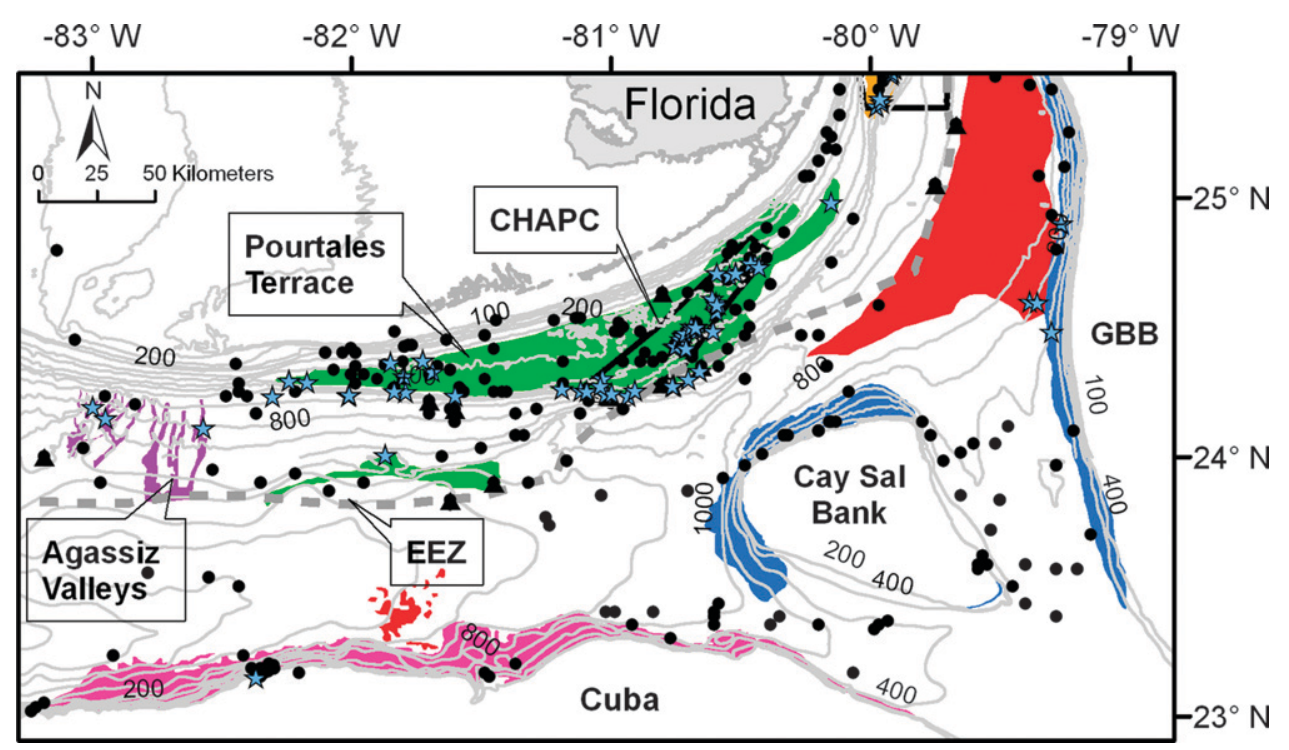

FIG. 4. Regions of deep-sea coral ecosystem (DSCE) habitats mapped in the southern Straits of Florida. (Same legend as Fig. 2)

These maps were only available as TIFF images, not as digitized depth contours. The following NOAA NOS regional bathymetric maps were used in our GIS project: NH17-6, NH17-9, NH17-12, NG17-3, NG17-6, NG17-9, NG17-12, L-184, and L-185. For the Straits of Florida, we also imported the Malloy and Hurley (1970) bathymetric maps which showed prominent features with 18-m contour resolution, and the Ballard and Uchupi (1971) map which provided very good detail in 5-m contours of the Miami Terrace.

All data were imported into ArcGIS and layered appropriately for best visualization. The data were then visually interpreted into vector polygons that delineated all variable and high relief $(>15 \mathrm{~m})$ features deeper than 200 meters (Figs. 1-4). Although not mathematically derived, visual interpretation of bathymetric data can yield high accuracies comparable to that of imagery in shallow waters (Walker et al. 2008). Given the data sources' formats, visual interpretation was the most practical. The coastal relief model DEM provided general detail for areas within its extent; however, the scanned NGDC bathymetric maps (NG, NH, and L series) and the maps of Malloy and Hurley (1970) and Ballard and Uchupi (1971) often provided greater resolution and detail of bottom features. The criteria used for recognizing a topographic feature as high relief were an elevation $>15 \mathrm{~m}$ in height and steep slopes relative to the surrounding flat bottom. Typically, individual coral mounds are 15 to $>150 \mathrm{~m}$ in height and $1-2 \mathrm{~km}$ in diameter although some exceed $6 \mathrm{~km}$. The slopes of individual mounds vary from $10-30^{\circ}$ and some may exceed $70-80^{\circ}$ on the upper flanks. In addition, steep rocky slopes were typically found on the escarpments of Miami and Pourtalès Terraces and on deep island slopes of the Bahamas and Cuba. Areas with multiple mounds in close proximity were mapped as one large unit. The planar area of each polygon was calculated in ArcGIS.

Submersible and ROV dives were used to ground-truth the vector polygons. From 1999 to 2009, deep-water coral sites were surveyed from northeastern Florida $\left(31^{\circ} \mathrm{N}\right)$ through the Straits of Florida between Florida, Bahamas and Cuba, using manned submersibles, ROVs and AUVs. To illustrate how the polygons were drawn, Figure 5 shows two types of bathymetric maps (NOAA-DEM, NOS Pillsbury NH 17-12) that were used in our ArcGIS project. The polygon (black line) was drawn in ArcGIS 

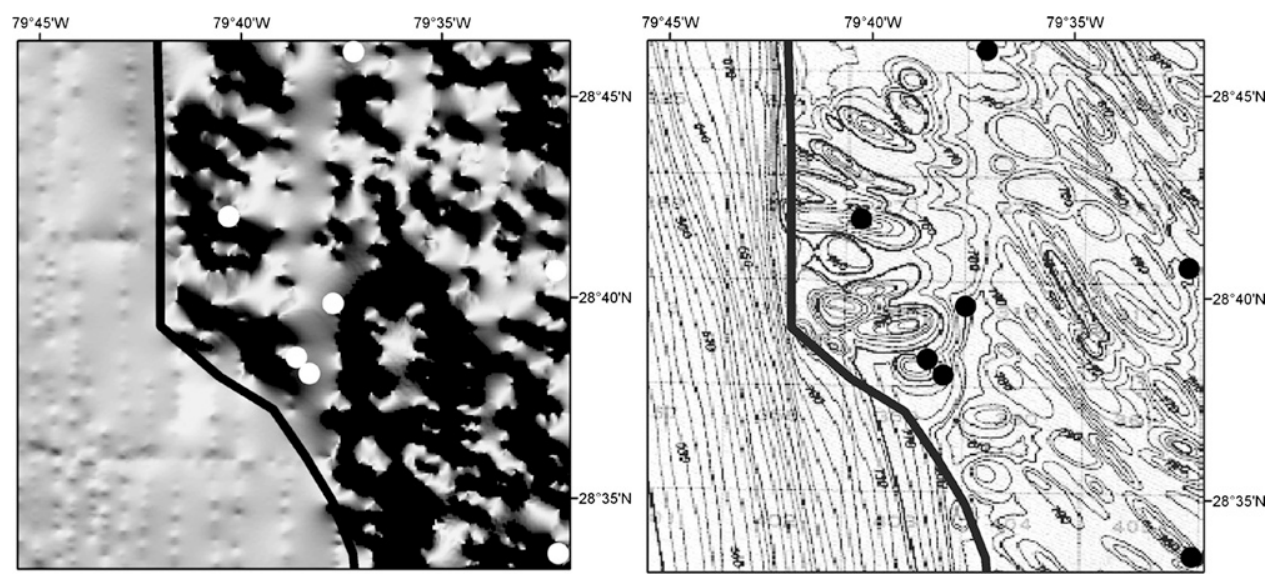

FIG. 5. Bathymetric maps used to draw polygon lines in GIS $\left(\mathrm{ArcView}^{\circledR}\right)$ around regions of high-relief bathymetry. Left: bathymetric map showing hill-shaded, 3-D topography (NOAA coastal relief digital elevation model); Right: NOAA NOS Pillsbury NH17-12 regional bathymetric map (10-m contour lines); dots= deep-water coral habitats ground-truthed with submersible dives. Smooth contour lines to west of high-relief polygon represent relatively flat mud of Florida-Hatteras Slope.

defining the delineation of the region of high-relief features from relatively flat bottom. Submersible dives ground-truthed several sites (black and white dots) within the polygon verifying the deep-sea coral habitat. The smooth depth contours of the FloridaHatteras mud slope are apparent to the west of the polygon in Figure 5.

Museum specimen records of deepwater, sessile, benthic species such as scleractinian corals collected by dredge and trawl may also be useful for mapping DSCE habitat. Although the precise locations of these records are less accurate than the more recent visual observations described above, they identify locations which could lead to the discovery of additional deep-sea coral habitat. Museum records (National Museum of Natural History, Smithsonian Institution) of deep-water scleractinian corals species collected by dredges or trawls (Cairns $1979,2000)$ were included as an additional ArcGIS layer.

\section{REsults}

\section{Bathymetric contour maps}

Based on the planar areal calculations in ArcGIS, the extent of probable deep-sea coral ecosystem (DSCE) habitat greater than $200 \mathrm{~m}$ depth from northeastern Florida $\left(31^{\circ} \mathrm{N}\right)$ through the Straits of Florida between Florida, Bahamas and Cuba yielded a total of $39,910 \mathrm{~km}^{2}$ (Figs. 1-4). Of this total DSCE area, $55.3 \%$ is within U.S. territorial waters; $34.7 \%$ is in the Bahamas off western Little Bahama Bank, western Great Bahama Bank and Cay Sal Bank; and $10.0 \%$ is off northern Cuba (Table 1). Figures 1-4 show the boundaries of the polygons but do not include all of the bathymetry layers of the GIS project that were used to determine the polygon boundaries such as is illustrated in Figure 5.

\section{Submersible, $R O V$, and AUV records}

We surveyed deep-water sites from 1999 to 2009 in this region of study using manned submersibles, ROVs and AUVs, during 16 cruises and 256 dives (189 submersible, $52 \mathrm{ROV}, 15 \mathrm{AUV})$. We estimate that the submersible dives covered $\sim 350 \mathrm{~km}$ of bottom, ROV $\sim 230 \mathrm{~km}$, and sonar surveys (ship and AUV) $\sim 567 \mathrm{~km}^{2}$.

Currently we have documented $>400$ high-relief, topographic target sites from sonar records (single-band sonar, side-scan sonar or multibeam sonar) at depths between 200 and $900 \mathrm{~m}$ that we suspect are deep-sea coral ecosystem habitats. Of these, we have ground-truthed 147 sites with 241 submersible and ROV dives throughout the geographical range of this study from 
TABle 1. Planar areal extent $\left(\mathrm{km}^{2}\right)$ of regions of deep-sea coral ecosystem habitat in the study area from northeastern Florida $\left(31^{\circ} \mathrm{N}\right)$ through the Straits of Florida between Florida, Bahamas and Cuba. Deep-water Coral Habitat Areas of Particular Concern (CHAPC) are within U.S. territorial waters only.

\begin{tabular}{|c|c|c|c|c|}
\hline Habitat Type & U.S. Florida & Western Bahamas & Northern Cuba & Total \\
\hline Coral Mounds $\mathrm{km}^{2}$ ( $\%$ of total) & $13,440(58.0 \%)$ & $9,482(41.0 \%)$ & $227(1.0 \%)$ & $23,149(100 \%)$ \\
\hline Island Slope $\mathrm{km}^{2}$ (\% of total) & - & $4,226(53.2 \%)$ & $3,723(46.8 \%)$ & $7,949(100 \%)$ \\
\hline $\begin{array}{l}\text { Miami Terrace and Escarpment } \mathrm{km}^{2} \\
\text { (\% of total) }\end{array}$ & $2,329(100 \%)$ & - & - & $2,329(100 \%)$ \\
\hline $\begin{array}{l}\text { Pourtalès Terrace and Escarpment } \mathrm{km}^{2} \\
\quad(\% \text { of total })\end{array}$ & $5,660(97.2 \%)$ & $154(2.6 \%)$ & $9(0.2 \%)$ & $5,823(100 \%)$ \\
\hline $\begin{array}{l}\text { Agassiz/Tortugas Valleys } \mathrm{km}^{2} \\
\text { (\% of total) }\end{array}$ & $628(95.2 \%)$ & - & $32(4.8 \%)$ & $660(100 \%)$ \\
\hline Total DSCE Habitat $\mathrm{km}^{2}$ (\% of total) & $22,057(55.3 \%)$ & $13,862(34.7 \%)$ & $3,991(10.0 \%)$ & $39,910(100 \%)$ \\
\hline $\begin{array}{l}\text { DSCE Habitat within CHAPC } \\
\text { (U.S. only) }\end{array}$ & $15,503(70.3 \%)$ & - & - & - \\
\hline $\begin{array}{l}\text { DSCE Habitat outside CHAPC } \\
\text { (U.S. only) }\end{array}$ & $6,554(29.7 \%)$ & - & - & - \\
\hline
\end{tabular}

north Florida to the southern Straits of Florida including both sides of the Straits and have documented the presence of DSCE habitat at every site (Figs. 2-4).

Figures 1 and 3 show a large, roughly triangular area (stripped polygon) just northwest of Great Bahama Bank that appears as a data gap in the DEM map, and in which we lack mapping and ground-truthed data although there are some museum records of deep-water scleractinian corals in this region (black dots). Although the narrower triangular portion of this zone north of $26^{\circ} 30^{\prime} \mathrm{N}$ falls within the broad swath of lithoherms indicated by Mullins and Neumann (1979) off Little Bahama Bank, the broader southern portion spans a broad triangular drift of prograding sediments that extends northward from the northwestern tip of Great Bahama Bank (Mullins and Neumann 1979, Mullins et al. 1980). This region is less likely to support extensive deep-water coral ecosystem habitat, but may include low-relief, submarine cemented hardgrounds overlaid by thin sand veneers (Mullins et al. 1980). A similar sediment drift extends off the northwestern tip of Little Bahama Bank (Mullins and Neumann 1979, Mullins et al. 1981) and may account for the triangular area where deep-water coral ecosystem habitat is not predicted to occur (Fig. 2).

Based on visual observations of the ground-truthed sites with submersible and ROV dives, we found that all high-relief dive sites consisted of deep-sea coral habitat; none were entirely soft-bottom habitat. Although the NOAA bathymetric maps were good indicators of high-relief hard bottom, the actual topography of the features typically were much more intricate than the maps showed due to the relatively low resolution of the original bathymetric data. For example, Figure 6 illustrates one site where the bathymetric map showed a slight but apparently insignificant dip in the $10-\mathrm{m}$ contour lines, but our AUV multibeam survey of the same site revealed five $50-\mathrm{m}$ tall mounds. These were later ground-truthed with submersible dives, revealing coverage with the densest growth of Lophelia coral thickets that we have found in the entire region (Reed and Farrington 2010). These maps were also inadequate in detecting low-relief pavements that may also provide habitat for deep-sea corals. Because low-relief rock pavements were difficult to visualize in the bathymetry, we did not generally survey them and thus we have likely underestimated the total area of deep-sea coral habitat in this region.

\section{Deep-sea coral ecosystem habitat}

Based on visual observations with submersibles and ROVs of the ground-truthed sites, we determined that there are six general regions of deep-sea coral ecosystem habitat in our study area and calculated 


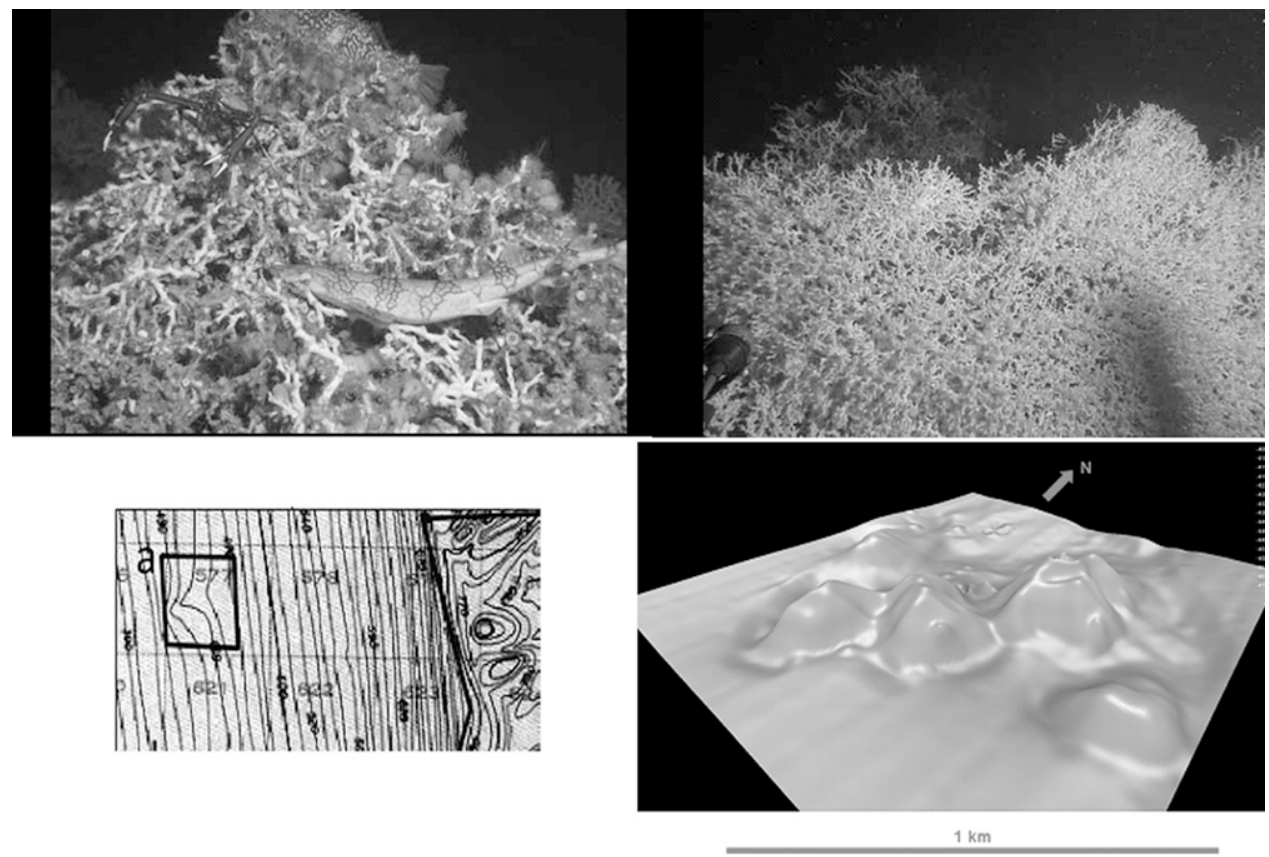

FIG. 6. Bathymetry and images of a deep-water Lophelia pertusa coral reef within the deep-water Coral Habitat Areas of Particular Concern off Cape Canaveral, Florida. Top- images from Johnson-Sea-Link submersible: Lophelia pertusa coral thickets with crabs and fish; lower left- 10-m contour lines from NOAA chart (Pillsbury NH 17-12); lower right- AUV multibeam sonar of same site showing five, $60-\mathrm{m}$ tall mounds over $1 \mathrm{~km}$ area.

the planar areal extent of each in ArcGIS (Table 1): 1) Lophelia pertusa and/or Enallopsammia profunda coral mounds (bioherms and lithoherms), 2) Miami Terrace and Escarpment, 3) Pourtalès Terrace and Escarpment, 4) Agassiz and Tortugas Valleys, and deep-water island slopes of 5) western Bahamas (which includes Cay Sal Bank) and 6) northern Cuba. These are discussed below.

Coral mounds (bioherms and lithoherms).Within the study area, high-relief L. pertusa and/or E. profunda coral mound habitat occurs primarily along the axis of the Gulf Stream and Florida Current from north Florida through the Straits of Florida and covers a total of $23,149 \mathrm{~km}^{2}$ (Figs. 1-4, red polygons). This habitat also extends north of the study area up to North Carolina within the boundaries of the CHAPCs but outside our area of study. We grouped both lithoherms and bioherms together as it is sometimes difficult to tell them apart; both are often covered with a veneer of coral debris and mud, and in general, share similar benthic assemblages.

Submersible dives showed that the slopes of these individual coral mounds are typically $15-30^{\circ}$ near the lower flanks and up to $60-90^{\circ}$ on the upper flanks (Reed et al. 2006). These are covered with various amounts of coral (from $<5 \%$ to $100 \%$ live coral cover) on the upcurrent slopes (facing the Gulf Stream or Florida Current) and peaks. Submersible surveys were also used to ground-truth three small sites $\left(\sim 80 \mathrm{~km}^{2}\right)$ in the Straits of Florida which had AUV multibeam data (Grasmueck et al. 2006, 2007). These revealed an additional 200 coral mounds with heights ranging from $1-83 \mathrm{~m}$ and footprint areas of 100-600,000 $\mathrm{m}^{2}$ (T. Correa, pers. comm.). The deep-water Oculina coral bioherms off central eastern Florida (Fig. 1) have similar structure as Lophelia bioherms, and we have extensively surveyed them with multibeam sonar and submersible and ROV dives, but we did not include them in this project as they occur at depths $<100 \mathrm{~m}$ (Reed 2002 a, Reed et al. 2005 b). 
Miami and Pourtalès Terraces and Escarpments.-The other habitat types of DSCE in this region are classified as hardbottom habitats. The Miami Terrace and the Pourtalès Terrace have complex karst-like topography of Tertiary limestones which form high-relief rock ridges, rock mounds, scarps, slabs, and rock pavement (Figs. 34). We estimate the areal cover of DSCE habitat for these two regions to be nearly 2,329 and $5,823 \mathrm{~km}^{2}$, respectively, or $20.4 \%$ of all DSCE habitat within our study area (Table 1). Bathymetric maps show the $145-\mathrm{km}$ long Miami Terrace Escarpment to extend as a steep slope from the top edge of the terrace at $\sim 275 \mathrm{~m}$ to the eastern base of the escarpment at 550-600 m. Submersible transects show this escarpment to be a series of terrace-like steps of rock slabs and ledges with $30-45^{\circ}$ slopes and sharp $90^{\circ}$ vertical escarpments up to $90 \mathrm{~m}$ in height (Neumann and Ball 1970, Ballard and Uchupi 1971, Reed et al. 2006). The top of the terrace consists of low- to moderate-relief rock pavement, rock slabs, and rubble or sediment veneer over rock (Messing et al. 2006). The Miami Terrace Escarpment ridges are capped with sponges and various corals, L. pertusa, Stylasteridae, Isididae, and other octocorals, whereas E. profunda coral mounds and coral rubble dominate near the foot of the escarpment. South of this, the Pourtalès Terrace parallels the Florida Keys for $213 \mathrm{~km}$ in the southern Straits of Florida at depths of 200-450 m, and provides extensive, highrelief, hard-bottom habitat (Jordan et al. 1964, Land and Paull 2000, Reed et al. 2005 a). It is bounded to the north by the sediment slope below the Florida Reef Tract and terminates to the south along the steep Pourtalès Escarpment. High-relief, hardbottom, topographic features consist numerous high-relief mounds and ridges on the mid-terrace and a chain of sinkholes that extends for $\sim 100 \mathrm{~km}$ along the southwest terrace margin.

Our submersible and ROV dives on both terraces documented DSCE benthic communities consisting of hard corals, stylasterid corals, black corals, gorgonians, and sponges (Reed et al. 2005 a, 2006). However, important distinctions exist between the benthic assemblages on the two terraces despite their relatively close proximity. In particular, thickets of L. pertusa and E. profunda are common on the Miami Terrace Escarpment, whereas stylasterid hydrocorals dominate the high-relief mounds on the Pourtalès Terrace and the other two coral species are rare. The reasons for these faunal differences remain unclear.

Agassiz and Tortugas Valleys.-The Agassiz and Tortugas Valleys have hard-bottom habitats and high-relief escarpments occurring at depths of 512-1,189 $\mathrm{m}$ near the western end of the Straits of Florida (Minter et al. 1975, Reed et al. 2005 a). The habitat polygons were drawn in ArcGIS along the steep escarpments of the valleys and covered $660 \mathrm{~km}^{2}$. Although we have limited data here, sonar surveys and a few Johnson-Sea-Link (J.Reed, unpublished data) and Alvin submersible dives (Minter et al. 1975) have documented steep rock walls and DSCE habitat. Our dives documented a sheer 140-m wall from depths of 760 to $900 \mathrm{~m}$ over $17 \mathrm{~km}$ in length. It appeared to be solid, consolidated clay mud, which supported sessile species. Large boulders at the bottom and rock pavement at the top edge both provided DSCE habitat. The extent of DSCE habitat on these steep vertical walls was difficult to determine using planar area measurements and is thus likely underestimated.

Deep Island Slopes of the western Bahamas and the northern Cuba.-The deep island slopes of the western Bahamas (i.e., Little Bahama Bank, Great Bahama Bank, and Cay Sal Bank) and the northern coast of Cuba represent another region of hard-bottom, deepsea coral habitat. The total area of possible DSCE habitat on these slopes is estimated to be $7,949 \mathrm{~km}^{2}$, or $19.9 \%$ of the total area of DSCE habitat in the study region (Table 1). The habitat polygons were drawn along apparent steep escarpment regions at depths of $200 \mathrm{~m}$ to $1000 \mathrm{~m}$ (Figs. 1-4). The geomorphology and benthic assemblages of the western Bahamas wall and slope was described by Neumann and Ball (1970), Neumann et al. (1977), Reed (1985), Reed and Pomponi (1997), and Messing et al. (1990). The deep forereef escarpment generally extends from depths of $50-100 \mathrm{~m}$ to 
$>200 \mathrm{~m}$ and consists of steep rocky slopes $\left(30-70^{\circ}\right)$ and vertical escarpments with ledges and undercuts. Below this, the deep island slope continues and consists of rock pavement, boulders, and mud slopes and extends to depths $>1000 \mathrm{~m}$ in some areas, especially in the southern Straits of Florida off Cuba. These hard-bottom, deep island slopes provide DSCE habitats, consisting primarily of gorgonians, black coral, and sponges, but thickets of colonial scleractinian corals appear uncommon at the sites that we have ground-truthed. The only ground-truth data we have for northern Cuba was from Johnson-Sea-Link submersible dives made for a film documentary. It is interesting to note that the deep fore-reef rocky slope habitat that is common off Bahamas and Cuba does not occur on the eastern and southern Florida shelf where the slope is primarily unconsolidated sediment. The shallow-water reefs that extend from the Florida Keys to central Florida generally end at depths of 30-40 m or less. Off north-central Florida, the Oculina coral reefs occur at depths of 60-100 m, whereas Miller's Ledge and Riley's Hump within the Tortugas Ecological Reserve of the Florida Keys National Marine Sanctuary provide hard-bottom, coral habitat to depths of 50-120 m. Recent coastal sonar surveys off southern and central Florida also indicate some hard-bottom ledges along the 70-90 m depth contours (Walker et al. 2004).

\section{Museum records}

Museum specimens of deep-water corals and other attached sessile benthic species collected by dredges or trawls may be useful indicators of potential hard-bottom DSCE habitat. Cairns $(1979,2000)$ reported 192 species of scleractinian corals within the tropical and warm temperate western Atlantic based on 6,900 specimens collected from 550 stations from the 1800s to the present, primarily from dredges and trawls, and housed in the National Museum of Natural History, Smithsonian Institution. Of the azooxanthellate species, 73 occur at depths $<183 \mathrm{~m}$, and 56 occur exclusively $>183 \mathrm{~m}$. We selected a depth of $50 \mathrm{~m}$ to divide deep-water occurrences from shallowwater in plotting on our ArcGIS maps.
Mesophotic reefs with zooxanthellate corals generally do not exceed depths of $50 \mathrm{~m}$ in this region. For example, Oculina varicosa forms zooxanthellate coral colonies at depths $<30 \mathrm{~m}$, but forms azooxanthellate high-relief reefs at depths $>50 \mathrm{~m}$. The depth of $>50 \mathrm{~m}$ was also selected to define 'deep corals' in NOAA's deep coral ecosystem report (Lumsden et al. 2007). A query of the above database (Cairns 1979, 2000) of all scleractinian corals occurring in the western Atlantic (southeastern U.S., Bahamas and Caribbean) at depths $>50 \mathrm{~m}$ resulted in 1,826 records. Of these, 53 records belong to the genera Lophelia, Enallopsammia or Madrepora, and ranged in the Straits of Florida from 91 to 1,336 $\mathrm{m}$ depths (shown as black triangles, Figs. 2-4). Our records of collections with submersibles (HBOI Museum, FAU) from the Straits of Florida provide an additional 79 records of occurrences for L. pertusa (172$828 \mathrm{~m}), 41$ for E. profunda (305-865 m), and 20 for M. oculata $(321-828 \mathrm{~m})$. Cairns $(1979,2000)$ also reported an additional 252 records of other deep-water stony coral genera, all solitary species, in the Straits of Florida in depths of 50-1,071 m (shown as black dots, Figs 2-4). We include these to show the extent of deepwater stony corals in this region: however, we did not include these sites in calculating the areal extent of hard bottom or DSCE habitat as some of these solitary taxa may occur on either hard- or soft-bottom habitat.

\section{Discussion}

\section{Areal extent of deep-sea coral ecosystem habitat}

All high-relief topographic features that we have ground-truthed to date within our region of study support deep-sea coral ecosystem (DSCE) habitat. Based on these data we are confident that high-relief features, as well as steep escarpments are good predictors of DSCE habitat in this region. Elsewhere, of course, other processes may also generate high-relief submarine features that are not hard bottom and our hypothesis is only relevant to this region of the Western Atlantic.

We estimate a total planar area of $39,910 \mathrm{~km}^{2}$ of DSCE habitat (>200 m depth) from northeastern Florida $\left(31^{\circ} \mathrm{N}\right)$ through 
the Straits of Florida between Florida and the Bahamas and Cuba. This exceeds the areal extent of shallow-water coral habitat for all U.S. waters, including Pacific and Caribbean territories to the U.S. Exclusive Economic Zone (EEZ; 36,813 km², Rohmann et al. 2005). In addition, the extent of deepwater coral habitat for the entire southeastern U.S. is even more massive, as it extends northward on the Blake Plateau and continental shelf margin from Georgia to North Carolina. Worldwide, deep-water coral reefs may cover as much area of seafloor as is estimated for all shallow warm-water reefs (Freiwald and Roberts 2005).

The South Atlantic Fishery Management Council, which manages fisheries for the southeastern U.S., has used our habitat polygons in part for defining the extent of DSCE habitat in this region for their newly designated, deep-water Coral Habitat Areas of Particular Concern (CHAPCs). The total area of the CHAPCs off the southeastern U.S., from North Carolina to south Florida, is $62,714 \mathrm{~km}^{2}$, which is $\sim 13 \%$ of the seafloor in U.S. waters in this region out to the EEZ $\left(493,218 \mathrm{~km}^{2}\right)$. An estimated $69 \%$ of the total area of the CHAPCs is off Florida $\left(43,393 \mathrm{~km}^{2}\right)$. Of the total $22,057 \mathrm{~km}^{2}$ of DSCE habitat that we estimate is in U.S. waters off Florida, we calculate that $15,503 \mathrm{~km}^{2}(70.3 \%)$ is within the Florida CHAPCs. This leaves approximately $6,554 \mathrm{~km}^{2}$ of DSCE habitat that remains unprotected $(29.7 \%)$ and outside the boundaries of the CHAPCs in U.S. waters off Florida, and of course, all the Bahamian and Cuban deep-sea coral habitat remains unprotected. Figure 1 shows at least seven areas of probable DSCE habitat that lie outside the CHAPCs off Florida. These include three areas of possible coral mound habitat off eastern Florida that are just west of the CHAPC boundary between $26^{\circ}$ and $31^{\circ} \mathrm{N}$; an area of hard-bottom habitat on the northwestern tip of the Miami Terrace; large portions of hard-bottom habitat on the Pourtalès Terrace and Escarpment; and the escarpment walls of the Tortugas and Agassiz Valleys.

\section{Distribution of Lophelia and Enallopsammia coral habitat}

Off the southeastern U.S., deep-water coral mounds occur at depths of approximately
400 to $1000 \mathrm{~m}$ from North Carolina to south Florida. Within our study area from $31^{\circ} \mathrm{N}$ to the southern Straits of Florida, L. pertusa and/ or E. profunda coral mounds occur as either bioherms (coral-capped mounds of mud and coral debris) or lithoherms (coral-capped rock mounds). These mounds are predominately L. pertusa but some are apparently entirely E. profunda, and some are intermixed. E. profunda appears especially common on the coral mounds off Great Bahama Bank and at the foot of the Miami Terrace (Reed et al. 2006, Grasmueck et al. 2007). Madrepora oculata is not a major contributor and occurs only as isolated, small colonies with either L. pertusa or E. profunda. For reasons unknown, extensive areas of dead E. profunda rubble are also common throughout the region and often at the bases of the mounds and the foot of the Miami Terrace.

On the western side of the Straits of Florida, the Lophelia/Enallopsammia coral mounds appear to terminate near the southern end of the Miami Terrace $\left(\sim 25^{\circ} 30^{\prime} \mathrm{N}\right)$ off Florida (Reed et al. 2006, Grasmueck et al. 2007). We have found none to date within U.S. waters in the southern Straits of Florida off the Florida Keys, Pourtalès Terrace or Agassiz and Tortugas Valleys. However, large coral mounds extend further south on the east side of the Straits along the foot of the Great Bahama Bank at least as far as $24^{\circ} 35^{\prime} \mathrm{N}$ (Grasmueck et al. 2007). Little data exists south of this in the deepest parts of the southern Straits of Florida and along the north coast of Cuba (Figs. 2, 3); however, a small region of high-relief mounds which may be coral habitat are apparent from the bathymetric maps off Cuba (Fig. 4). Grasmueck et al. $(2006,2007)$ compared deep-water coral mounds on the eastern and western sides of the Straits of Florida between Miami and Great Bahama Bank and found relatively similar temperatures but strikingly different current regimes. Sites off Great Bahama Bank showed tidal currents, which reversed $\mathrm{N}$ and $S$ daily, whereas currents at the foot of the Miami Terrace on the west side of the Straits were predominantly southerly due to a persistent counterclockwise bottom gyre. Elsewhere in the Straits of Florida and off northeastern Florida, bottom currents during our submersible dives were always northerly 
due to the Florida Current and Gulf Stream. In this region, coral growth is always densest on mound peaks and flanks facing the current, and thus we found the densest growth on the south faces of mounds throughout the Straits of Florida except for the Miami Terrace sites where the densest growth was on the northern slopes due to the counter current.

In contrast to the coral bioherms, lithoherms dominate off north Florida and off Little Bahama Bank along the eastern side of the northern Straits of Florida. Off northeastern Florida, Paull et al. (2000) described the geology of an extensive system of deep-water lithoherms at depths of 440 to $>900 \mathrm{~m}$. They postulated that over 40,000 individual lithoherms on the Blake Plateau and Straits of Florida may exceed the areal extent of all the shallow-water reefs of the southeastern U.S. Individual mounds reach $1000 \mathrm{~m}$ long, $300 \mathrm{~m}$ wide and $40 \mathrm{~m}$ high. They have steep $\left(30-60^{\circ}\right)$ slopes armored by lithified crusts. Thickets of coral (L. pertusa and E. profunda) cap the tops and southern flanks, which face the Gulf Stream. The other region of lithoherms, off Little Bahama Bank, form 50-m high elongated lithified mounds at depths of 500-700 m (Neumann et al. 1977, Messing et al. 1990). They are composed of hardened concentric crusts of lithified muddy carbonate sediment and appear to be constructed by subsea lithification of successive layers of trapped sediment and skeletal debris. The largest are capped by thickets of living L. pertusa, often with dense stands of the large flabellate zoanthid, Gerardia sp., on crests and upper flanks.

Unlike the coral bioherms, the Miami and Pourtalès Terraces are primarily limestone rock. The Miami Terrace Escarpment ridges are capped with L. pertusa, Stylasteridae, Isididae, and various sponges and octocorals; E. profunda coral mounds and coral rubble dominate near the eastern foot of the escarpment. Whereas the Miami Terrace has thickets of $L$. pertusa and E. profunda, the Pourtalès Terrace, just $85 \mathrm{~km}$ to the south, supports deep-sea coral habitat dominated by stylasterid hydrocorals and accompanied by gorgonians and sponges, but submersible dives have found only a few isolated L. pertusa colonies, primarily along the edges of sinkholes. The reasons for these faunal differences remain unclear, especially because both Terrace habitats lie in the Florida Current, and at depths and temperatures suitable for L. pertusa.

As might be expected from the broad worldwide distribution of cold-water corals, DSCEs occur in a wide range of geologic settings. In addition to bioherms and lithoherms, deep-sea corals are associated with authigenic carbonate outcrops in the Gulf of Mexico (Schroeder 2001), seamountcrest mega-ripples off Spain (Freiwald 2000), submarine canyons off Canada (Mortensen \& Bühl-Mortensen 2005), and iceberg plough marks and glacial moraines off Norway (Freiwald et al. 1999, Mortensen et al. 2001).

\section{Predicting deep-sea coral ecosystem habitat}

It is estimated that $95 \%$ of all records of deep-sea, framework-forming corals occur in the Atlantic Ocean and primarily in the northeast and northwest Atlantic (Guinotte et al. 2006). By using ecological-niche factor analysis (ENFA), Davies et al. (2008) determined that the primary predictors for the occurrence of L. pertusa on both the global and regional scales were mean depths of 468-480 m, higher than average currents and productivity, mean temperatures of 6.2-6.7 ${ }^{\circ} \mathrm{C}$, dissolved oxygen of $5.98 \mathrm{ml} \mathrm{l}^{-1}$, seawater saturated with aragonite (i.e., above the aragonite saturation horizon), and low concentrations of nutrients (silicate, phosphate, and nitrate). They further defined two main hypotheses for the environmental predictors for deep coral distribution. In the Current Acceleration Hypothesis (Mortensen et al. 2001), deep-sea coral reefs occur in areas of accelerated currents and sloping topography or topographic highs, where currents tend to concentrate food supply and may limit or reduce sedimentation. According to the Hydraulic Theory (Hovland and Thomsen 1997), deep-sea coral reefs are associated with seepage of hydrocarbons through the seafloor. Although hydrocarbon seeps are commonly associated with many of the deepsea coral communities in the Gulf of Mexico (Brooke and Schroeder 2007), we have seen 
no evidence of seeps on the coral mounds of the southeastern U.S. Roberts et al. (2009) largely discounted the Hydraulic Theory in the eastern Atlantic as well. Recent JohnsonSea-Link submersible dives using a methane detector on various coral mounds in the Straits of Florida found no evidence of any significant methane peaks (M. Grasmueck, Univ. Miami, personal communication). However, a definitive answer will require more extensive surveys and analyses.

In this region off the southeastern U.S., the Current Acceleration Hypothesis applies, as do the predictors of the ENFA model. All areas are bathed by the Florida Current and Gulf Stream, which provide suspended food that all local habitat-forming sessile cnidarians and sponges require. Much of the DSCE habitat is associated with topographic highs or escarpments. Although near-seafloor data for physical factors is limited, the ranges recovered by the occasional submersible or ROV dive are similar to those reported by Davies et al. (2008). In our ROV and submersible dataset, the depth range was 250 to $914 \mathrm{~m}$ (maximum depth of the submersible), bottom temperatures $6.2-12.6^{\circ} \mathrm{C}$ (chiefly 6-10 ${ }^{\circ} \mathrm{C}$ ), salinities 34.0-36.4 ppt, currents $0-100 \mathrm{~cm} \mathrm{~s}^{-1}$ (chiefly $10-30 \mathrm{~cm} \mathrm{~s}^{-1}$ ), and dissolved oxygen 2.79-3.2 $\mathrm{mg} \mathrm{l}^{-1}$ (Reed et al. $2005 \mathrm{a}$, 2006). Only dissolved oxygen appears lower at our sites than the mean for the ENFA analyses $\left(5.9 \mathrm{ml} \mathrm{l}^{-1}\right)$. We predict that deepwater corals could occur anywhere in this region where proper depth $(>200 \mathrm{~m})$ and suitable substrate occur for coral attachment. However, Davies et al. (2008) pointed out that not all occurrences of L. pertusa rely upon large amounts of hard substrate. Larval settlement may also occur on small cobble (Wilson 1979).

During the Southeast Area Monitoring and Assessment Program (SEAMAP, Arendt et al. 2003), the senior author (J.Reed) compiled a list of benthic genera occurring in 200-2000 m that would most likely indicate hard-bottom habitat on the Blake Plateau and Straits of Florida. Numerous deep-water sessile organisms (including hard corals, octocorals, black corals, sponges, hydroids, and stalked crinoids) typically require hardbottom substrate. Museum records of these taxa could predict probable hard-bottom habitat. The following summarizes the number of these taxa in this region:

$$
\begin{aligned}
& \text { Porifera, Demospongiae (121 genera) } \\
& \text { Cnidaria, Hydrozoa, Stylasteridae (8 genera) } \\
& \text { Cnidaria, Octocorallia ( } 64 \text { genera) } \\
& \text { Cnidaria, Scleractinia ( } 56 \text { genera) } \\
& \text { Cnidaria, Antipatharia (13 genera) } \\
& \text { Echinodermata, Crinoidea (7 genera, stalked } \\
& \text { taxa). }
\end{aligned}
$$

Of these, only the Scleractinia were compiled from museum records and entered into our ArcGIS database as described above. Numerous museums have electronic databases for their marine invertebrate collections that allow for some queries of their inventories for this region, although many are incomplete and do not represent entire holdings. It is uncertain whether the time required for searching through the records of each of these 287 taxa would significantly add to the predictability of hard-bottom habitat distributions in the region.

\section{Conservation}

Energy development and bottom fishing represent two primary threats to deep-sea coral ecosystems worldwide and especially in the southeastern U.S. Prior to 2008, a moratorium on oil and gas development off the Florida coast prevented potential impact; however, recent U.S. legislation possibly lifting the moratorium, and exploration in adjacent Cuban waters has increased this threat. More recently, we have seen the potential impact to DSCEs downstream of the massive oil spill from the Deepwater Horizon drilling site in the Gulf of Mexico. During the spill in July of 2010, Harbor Branch Oceanographic Institute scientists used the Johnson-Sea-Link submersible to investigate potential impacts of the oil on deep-water and mesophotic (shelf edge) reefs along the west Florida shelf and Florida Keys. Luckily to date, we have seen no evidence of oil on these habitats except for one report of dead deep-sea coral approximately $11 \mathrm{~km}$ from the well site at 1,400 m depth (C. Fisher, Penn State Univ.). Natural gas pipelines and renewable energy 
projects such as ocean turbines that are currently being considered in this region could also directly impact these habitats (Messing et al. 2006, 2008).

Recently, five deep-water Coral Habitat Areas of Particular Concern (CHAPCs) were established off southeastern U.S. from North Carolina to south Florida, encompassing 62,714 $\mathrm{km}^{2}$ (NOAA 2010). These sites were originally proposed by the South Atlantic Fishery Management Council (SAFMC 2009) which manages fisheries for the southeastern U.S. through the Magnuson-Stevens Fishery Conservation and Management Act (Fig. 1; http://www.safmc.net/ecosystem/ HabitatManagement/DeepwaterCorals). The SAFMC adopted recommendations developed by its Coral and Habitat Advisory Panels after nearly six years of extensive research by numerous scientists and discussions with state, federal and local managers; conservation representatives; and fishing industry representatives (Reed 2004, Ross 2004). These CHAPCs were established in response to concerns about potential impacts of benthic fisheries in this region on coral and hard-bottom habitats. The CHAPCs prohibit or restrict bottom-tending fisheries such as bottom trawls, longlines, dredges and traps (Brouwer et al. 2008). Potential fisheries at these depths are golden crab (Chaceon fenneri), blueline tilefish (Caulolatilus microps), golden tilefish (Lopholatilus chamaeleonticeps), and various species called royal red shrimp (chiefly Pleoticus robustus). All of these species have been observed during dives with human occupied submersibles and ROVs (Reed and Farrington 2010).

Protection such as established with the deep-water CHAPCs will help prevent long-term damage from bottom trawling, which has occurred on the deep-sea coral ecosystems worldwide (Fosså et al. 2002). In Florida waters, fishing virtually eliminated high densities of economically important reef fish and large spawning aggregations of grouper on the deep-water Oculina varicosa coral reefs (Gilmore and Jones 1992, Koenig et al. 2005), and bottom trawling for rock shrimp severely impacted the coral habitat with up to $100 \%$ coral loss on some Oculina reefs (Koenig et al. 2005, Reed et al. 2007). In 1984, NOAA designated a $315-\mathrm{km}^{2}$ region as the deep-water Oculina coral Habitat Area of Particular Concern (OHAPC), which established the first deep-sea coral marine protected area in the world and prohibited bottom trawling, dredging, and bottom longlines. This area was expanded to $1,029 \mathrm{~km}^{2}$ in 2000 . After trawling for rock shrimp was prohibited in the OHAPC, trawlers moved to deeper habitats in search of valuable commercial fisheries, such as royal red shrimp. The resource potential of the deep-water habitats in this region is great, both in terms of fisheries and potential novel biopharmaceutical compounds recently discovered from associated fauna such as sponges (Guzmán et al. 2009, Wright et al. 2009).

Designation of deep-sea coral ecosystems as HAPCs does not regulate nor protect them from potential energy development such as proposed LNG pipelines, oil and gas exploration, and renewable energy projects. Deep-sea coral ecosystems are extremely complex and would take decades to recover from direct impact, if at all. This is particularly evident with the deepwater Oculina reefs where after 25 years of protection, little new coral growth is evident in damaged areas (Reed et al. 2007). It is therefore critically important to map these habitats with high resolution sonar and visual surveys in order to provide the best available scientific data for developing legislation and protection from potential human impact. Not only are high resolution surveys critical to define DSCE habitats but also to define areas devoid of coral and sponge habitat to allow for potential bottom fisheries and energy development.

Acknowledgments.-Numerous individuals have contributed to this research over many years. R Avent (Harbor Branch Oceanographic Foundation) initiated the submersible studies of Florida's deep-water reefs in the 1970s. We especially thank the Robertson Coral Reef Research and Conservation Program and the Division of Biomedical Marine Research at Harbor Branch Oceanographic Institute, Florida Atlantic University (HBOI/FAU) for contributing funding to these studies. We thank NOAA's 
Cooperative Institute for Ocean Exploration, Research, and Technology at HBOI. NOAA's Office of Ocean Exploration funded expeditions ("Florida's Deep-water Oases: Exploration of Deep Reef Ecosystems") in 2002, 2003, 2005 and 2006. The State of Florida funded the Center of Excellence in Biomedical and Marine Biotechnology (HBOI and Florida Atlantic University) which provided ship and submersible time in 2004 and 2005. The Waitt Institute for Discovery, Catalyst One Program, provided AUV and ship time in 2008. Corporate sponsored research included: Calypso U.S. Pipeline LLC, "Deep-water Marine Benthic Video Survey [ROV] of Proposed Liquid Natural Gas Pipeline [Route]"; Calypso U.S. Pipeline LLC, "Marine Benthic Video Survey [ROV] of Proposed Liquid Natural Gas Port [Facility]"; Seafarer U.S. Pipeline System Inc., "Deepwater Submersible Survey of Proposed Natural Gas Pipeline Route"; Columbus Networks, Tyco Telecommunications Inc., "Deep-water Benthic Video Survey [ROV] of Proposed Telecom Cable Route". The various crews of HBOI's research vessels R/V Seward Johnson I and II, R/V Sea Diver, and the Johnson-Sea-Link and Clelia submersibles are gratefully thanked for their support, without which this research would not have been possible. The South Atlantic Fishery Management Council is gratefully acknowledged for assuming the task of protecting these deep-water coral reefs with their proposed $62,714 \mathrm{~km}^{2}$ deepwater Coral Habitat Areas of Particular Concern. This is Contribution Number 1819 from Harbor Branch Oceanographic Institute, Florida Atlantic University.

\section{Literature Cited}

Arendt, M. D., C. A. Barans, G. R. Sedberry, R. Van Dolah, J. Reed, and S. Ross. 2003. Summary of seafloor mapping and benthic sampling in 200-2000 m from North Carolina through Florida. Final report for phase II of the deepwater habitat mapping project. South Atlantic Fishery Management Council, NOAA Coastal Services Center, 157 p.

Ballard, R. and E. Uchupi. 1971. Geological observations of the Miami Terrace from the submersible Ben Franklin. Marine Technology Society Journal 5:43-48.

Brooke, S. D. and W.W. Schroeder. 2007. State of deep coral ecosystems in the Gulf of Mexico region:
Texas to the Florida Straits. In The State of Deep Coral Ecosystems of the United States, eds. S. E. Lumsden, T. F. Hourigan, A. W. Bruckner, and G. Dorr, 271-306. NOAA Technical Memorandum CRCP-3, Silver Spring, MD.

Brouwer, M, R. Pugliese, J. Reed, S. Ross, and T. Udouj. 2008. Managing deepwater coral ecosystems off the southeastern United States. 2008 International Deep Sea Coral Symposium, New Zealand, p. 135.

Cairns, S. D. 1979. The deep-water Scleractinia of the Caribbean Sea and adjacent waters. Studies on the Fauna of Curacao and Other Caribbean Islands 56:1-341.

Cairns, S. D. 2000. A revision of the shallow-water azooxanthellate scleractinia of the Western Atlantic. Studies of the Natural History of the Caribbean Region, 75:1-240.

Correa, T. B. S., G. Eberli, M. Grasmueck, John Reed, A. Correa. 2012. Genesis and morphology of coldwater coral ridges in a unidirectional current regime. Marine Geology 326-328:14-27.

Davies, A. J., M. Wisshak, J. C. Orr, and J. M. Roberts. 2008. Predicting suitable habitat for the cold-water coral Lophelia pertusa (Scleractinia). Deep-Sea Research I 55:1048-1062.

Etnoyer, P., S. D. Cairns, J. A. Sanchez, J. Reed, J. Lopez, W. Schroeder, S. Brooke, L. Watling, A. Baco-Taylor, G. Williams, A. Lindner, S. France, and A. Bruckner. 2006. Deep-sea coral collection protocols. NOAA Technical Memorandum NMFSOPR $-28,53 \mathrm{p}$.

Fosså, J. H., P. B. Mortensen, and D. M. Furevik. 2002. The deep-water coral Lophelia pertusa in Norwegian waters: distribution and fishery impacts. Hydrobiologia 417:1-12.

Freiwald, A. 2000. The Atlantic coral ecosystem study (ACES): a margin-wide assessment of corals and their environmental sensitivities in Europe's deep waters. EurOCEAN 2000 Project Synopses, 317 p.

Freiwald, A. J. B. Wilson, and R. Henrich. 1999. Grounding Pleistocene icebergs shape recent deep-water coral reefs. Sedimentary Geology 125:1-8.

Freiwald, A. and J. M. Roberts, eds. 2005. Coldwater Corals and Ecosystems. Berlin Heidelberg: Springer-Verlag.

Gilmore, R. G. and R. S. Jones. 1992. Color variation and associated behavior in the epinepheline groupers, Mycteroperca microlepis (Goode and Bean) and $M$. phenax Jordan and Swain. Bulletin of Marine Science 51:83-103.

Grasmueck, M., G. P. Eberli, D. Viggiano, T. Correa, G. Rathwell, and J. Luo. 2006. Autonomous underwater vehicle (AUV) mapping reveals coral mound distribution, morphology, and oceanography in deep water of the Straits of Florida. Geophysical Research Letters 33:L23616, 6 p.

Grasmueck, M., G. P. Eberli, T. Correa, D. Viggiano, J. Luo, G. Wyatt, A. Wright, J. Reed, and S. Pomponi. 2007. AUV-based environmental characterization of deep-water coral mounds in the Straits of Florida. 2007 Offshore Technology Conference, Houston, Texas, 12 p. 
Guinnotte, J. M., J. C. Orr, S. D. Cairns, L. Morgan, and R. George. 2006. Will human-induced changes in seawater chemistry alter the distribution of deepsea scleractinian corals? Frontiers in Ecology and the Environment 4(3):141-146.

Guzmán, E. A., J. D. Johnson, C. Meyer, M. Carrier, T. Pitts, S. Gunasekera, and A. Wright. 2009. Selective cytotoxic activity of the marine derived batzelline compounds against pancreatic cancer cell lines. Anticancer Drugs 20(2):149-155.

Hain, S. and E. Corcoran, eds. 2004. 3. The status of the cold-water coral reefs of the world. In Status of coral reefs of the world: 2004. Vol. 1., ed. C. Wilkinson, 115-135. Perth: Australian Institute of Marine Science.

Hovland, M. and E. Thomsen. 1997. Cold-water corals- are they hydrocarbon seep related? Marine Geology 137(1-2):83-96.

Jordon, G., R. Malloy, and J. Kofoed. 1964. Bathymetry and geology of Pourtalès Terrace. Marine Geology $1: 259-287$.

Koenig, C. C., A. N. Shepard, J. K. Reed, F. Coleman, S. Brooke, J. Brusher, and K. Scanlon. 2005. Habitat and fish populations in the deep-sea Oculina coral ecosystem of the western Atlantic. American Fisheries Society Symposium 41:795-805.

Land, L. A. and C. Paull. 2000. Submarine karst belt rimming the continental slope in the Straits of Florida. Geo-Marine Letters 20:123-132.

Lumsden, S. E., T. F. Hourigan, A. W. Bruckner, and G. Dorr, eds. 2007. The State of Deep Coral Ecosystems of the United States. NOAA Technical Memorandum CRCP-3, Silver Spring, MD.

Malloy, R. J. and R. Hurley. 1970. Geomorphology and geologic structure: Straits of Florida. Geological Society of America Bulletin 81:1947-1972.

Messing, C. G., A. C. Neumann, and J. C. Lang. 1990. Biozonation of deep-water lithoherms and associated hardgrounds in the northeastern straits of Florida. Palaios 5:15-33.

Messing, C. G., J. K. Reed, S. D. Brooke, and S. W. Ross. 2008. Deep-water coral reefs of the United States. In Coral reefs of the USA, eds. B. M. Riegl and R. E. Dodge, 767-791. Springer.

Messing, C.G., J. K. Reed, S. D. Brooke, B. Walker, and R. Dodge. 2006. Calypso LNG deepwater port project, Florida marine benthic video survey, final report. A report to Ecology and Environment, Inc. and Suez Inc., $60 \mathrm{p}$.

Minter, L.L., G. Keller, and T. Pyle. 1975. Morphology and sedimentary processes in and around Tortugas and Agassiz Sea Valleys, southern Straits of Florida. Marine Geology 18:47-69.

Mortensen, P. B., M. T. Hovland, J. H. Fosså, and D. M. Furevik. 2001. Distribution, abundance and size of Lophelia pertusa coral reefs in mid-Norway in relation to seabed characteristics. Journal of Marine Biological Association, U.K. 81:581-597.

Mortensen, P. B. and L. Bühl-Mortensen. 2005. Deepwater corals and their habitats in The Gully, a submarine canyon off Atlantic Canada. In Cold-water
Corals and Ecosystems. Eds. A. Freiwald and J. M. Roberts, 247-277. Berlin Heidelberg: Springer-Verlag. Mullins, H.T., and A. C. Neumann. 1979. Deep carbonate bank margin structure and sedimentation in the northern Bahamas: SEPM Special Publication, no. 27:165-192.

Mullins, H T., A. C. Neumann, R. J. Wilber, A. C. Hine, and S. J. Chinburg. 1980. Carbonate Sediment Drifts in Northern Straits of Florida. American Association of Petroleum Geologists Bulletin 64(10):1701-1717.

Mullins, H. T., C. R. Newton, K. C. Heath, and H. M. Van Buren. 1981. Modern deep-water coral mounds north of Little Bahama Bank: criteria for the recognition of deep-water coral bioherms in the rock record. Journal Sedimentary Petrology 51:999-1013.

Neumann, A. C. and M. M. Ball. 1970. Submersible observations in the Straits of Florida: geology and bottom currents. Geological Society American Bulletin 81:2861-2874.

Neumann, A. C., G. H. Kofoed, and G. H. Keller. 1977. Lithoherms in the Straits of Florida. Geology 5:4-10.

NOAA. 2010. Fisheries of the Caribbean, Gulf of Mexico, and South Atlantic; comprehensive ecosystem-based amendment for the South Atlantic Region. Federal Register, 75(119):35330-35335.

Paull, C. K., A. Neumann, B. am Ende, W. Ussler, and N. Rodriguez. 2000. Lithoherms on the FloridaHatteras slope. Marine Geology 166:83-101.

Partyka, M.L., S. W. Ross, A. Quattrini, G. Sedberry, T. Birdsong, J. Potter, and S. Gottfried. 2007. Southeastern United States deep-sea corals (SEADESC) initiative: a collaborative effort to characterize areas of habitat-forming deep-sea corals. NOAA Technical Memorandum OAR OER 1, 176 p.

Reed, J. K. 1980. Distribution and structure of deepwater Oculina varicosa coral reefs off central eastern Florida. Bulletin of Marine Science 30:667-677.

Reed, J. K. 1985. Deepest distribution of Atlantic hermatypic corals discovered in the Bahamas. Proceedings Fifth International Coral Reef Congress 6:249-254.

Reed, J. K. 2002 a. Comparison of deep-water coral reefs and lithoherms off southeastern U.S.A. Hydrobiologia 471:57-69.

Reed, J. K. 2002 b. Deep-water Oculina coral reefs of Florida: biology, impacts, and management. Hydrobiologia 471:43-55.

Reed, J. K. 2004. General description of deep-water coral reefs of Florida, Georgia and South Carolina: a summary of current knowledge of the distribution, habitat, and associated fauna. South Atlantic Fishery Management Council, NOAA, National Marine Fisheries Service, $71 \mathrm{p}$.

Reed, J. K. 2008. WAITT Catalyst One Project, AUV sonar survey of Florida's deep water coral reefs, expedition science summary report. WAITT Institute for Discovery. Accessed 25 August 2009. http://wid.waittinstitute.org/

Reed, J. and S. Farrington. 2010. Distribution of deepwater commercial fisheries species-golden crab, tilefish, royal red shrimp- in deep-water habitats 
off eastern Florida from submersible and ROV dives. South Atlantic Fishery Management Council and NOAA National Marine Fisheries Service, 163 pp.

Reed, J. and S. Pomponi. 1997. Biodiversity and distribution of deep and shallow water sponges in the Bahamas. Proceedings of the Eighth International Coral Reef Symposium 1:1387-1392.

Reed, J. K., S. Pomponi, A. Wright, D. Weaver, and C. Paull. 2005 a. Deep-water sinkholes and bioherms of South Florida and Pourtalès Terrace- habitat and fauna. Bulletin of Marine Science 77:267-296.

Reed, J. K., A. Shepard, C. Koenig, K. Scanlon, and G. Gilmore. 2005b. Mapping, habitat characterization, and fish surveys of the deep-water Oculina coral reef Marine Protected Area: a review of historical and current research. In Cold-water Corals and Ecosystems, eds. A. Freiwald and J. Roberts, 443-465. Berlin Heidelberg: Springer-Verlag.

Reed, J. K., D. Weaver D, and S. Pomponi. 2006. Habitat and fauna of deep-water Lophelia pertusa coral reefs off the Southeastern USA: Blake Plateau, Straits of Florida, and Gulf of Mexico. Bulletin of Marine Science 78(2):343-375.

Reed, J. K., C. C. Koenig, and A. N. Shepard. 2007. Impacts of bottom trawling on a deep-water Oculina coral ecosystem off Florida. Bulletin of Marine Science 81:481-496.

Roberts, M., A. Wheeler, A. Freiwald, and S. Cairns. 2009. Cold-water Corals. The Biology and Geology of Deep-sea Coral Habitats. Cambridge University Press.

Rogers, A. D. 1999. The biology of Lophelia pertusa (Linnaeus 1758) and other deep-water reefforming corals and impacts from human activities. International Revue Hydrobiologia 84:315-406.

Rohmann, S. O., J. J. Hayes, R Newhall, M. Monaco, and R. Grigg. 2005. The area potential of shallowwater tropical and subtropical coral ecosystems in the United States. Coral Reefs 24:370-383.

Ross, S. W. 2004. General description of distribution, habitat, and associated fauna of deep water coral reefs on the North Carolina continental slope. South Atlantic Fishery Management Council, NOAA, National Marine Fisheries Service, 14 p.

Ross, S. W., and M. S. Nizinski. 2007. State of deep coral ecosystems in the U.S. southeast region: Cape Hatteras to southeastern Florida. In The State of Deep Coral Ecosystems of the United States, eds. S. E.
Lumsden, T. F. Hourigan, A. W. Bruckner, and G. Dorr, 233-269. NOAA Technical Memorandum CRCP-3, Silver Spring, MD.

Ross, S. W., and A. M. Quattrini. 2007. The fish fauna associated with deep coral banks of the southeastern United States. Deep Sea Research Part 1 54:975-1007.

South Atlantic Fishery Management Commission. 2009. Comprehensive ecosystem-based amendment 1. South Atlantic Fishery Management Council, NOAA National Marine Fisheries Service.

Schroeder, W.W. 2001. Video documentation of the geology and distribution of Lophelia prolifera at a deep-water reef site in the northeastern Gulf of Mexico. In Proceedings of First International Symposium on Deep-sea Corals, eds. J. H. Willison, J. Hall, S. Gass, E. Kenchington, M. Butler, and P. Doherty, 224-225. Halifax: Ecology Action Centre, Nova Scotia Museum.

Stetson, T. R., D. F. Squires, and R. M. Pratt. 1962. Coral banks occurring in deep water on the Blake Plateau. American Museum Novitates 2114:1-39.

Udouj, T. 2007. Final report, deepwater habitat mapping project, phase III. Partnership with the FWC Florida Fish and Wildlife Research Institute in the recovery, interpretation, integration and distribution of bottom habitat information for the South Atlantic Bight (200-2000 m). South Atlantic Fishery Management Council, NOAA Coastal Services Center, 16 p.

Walker, B. K., B. Riegl, and R. E. Dodge. 2008. Mapping coral reef habitats in southeast Florida using a combined technique approach. J. Coast. Res. 24:1138-1150.

Walker B.K., B. Riegl, K. Banks, and R.E. Dodge. 2004. Quarternary sea-level rise and reef backstepping in Southeast Florida. 10th International Coral Reef Symposium. Abstract, p. 266.

Wilson, J. B. 1979. The distribution of the coral Lophelia pertusa (L) [L. prolifera (Pallas)] in the northeast Atlantic. Journal Marine Biological Association, U. K. 59:149-164.

Wright, A. E., G. Roth, J. Hoffman, D. Divlianska, D. Pechter, S. Sennett, E. Guzmán, P. Linley, P. McCarthy, T. Pitts, S. Pomponi, and J. Reed. 2009. Isolation, synthesis and biological activity of aphrocallistin, an adenine substituted bromotyrosine metabolite from the Hexactinellida sponge Aphrocallistes beatrix. Journal Natural Products 72(6):1178-83. 